\title{
CROSS-COUNTRY ANALYSIS ON NEIGHBORING MIGRATION POLICY BY THE EXAMPLE OF FINLAND AND RUSSIA
}

\author{
Maria Pitukhina ${ }^{1}$, Svetlana Shabayeva ${ }^{2}$ and Andrej Privara ${ }^{3}$ \\ ${ }^{1}$ Petrozavodsk State University, Russia \\ ${ }^{2}$ Petrozavodsk State University, Russia \\ ${ }^{3}$ University of Economics in Bratislava, Slovakia
}

\begin{abstract}
Article deals with, in particular, migration influence on both qualitative and quantitative human capital parameters in a recipient country. Currently Russian migration policy is under transition - the necessity of taking serious measures is acute, especially taking into account migrants' human capital parameters such as education. Tajikistan, Kirgizia, Armenia are main countries of migrants' origins in Russia. Migrants from these countries are mainly unskilled, poorly educated, low wage labor. Migration policy in Finland is considered to be highly adaptive and balanced. Reasons for Finland's success are the best European projection system of labour market parameters; VET and higher education development; skills anticipation; information dissemination in society; lifelong learning implementation. There is a variety of methods widely applied in the article qualitative evaluation of labour market parameters, desk studies, documents analysis, and comparative research. The research reflects on the OECD indicators "Education at Glance" 2011; Statistics Russia; Russian Strategy 2020 - a new model of growth; National Finnish Acts 1994, 1999, 2003, 2004; Concept on state migration policy in Russia till 2025; EUROSTAT etc. Authors conclude that Russian migration policy shall implement Finnish approach since only full and up-todate data will contribute to the result-oriented decision-making process.
\end{abstract}

Keywords: Education in a Multicultural Society, Foreign Labour Migration, Human Capital

\section{Introduction}

One of the recent trends - foreign labour migrants increase both in the European Union (EU) and Russia - is conditioned on by population ageing and huge decrease of active working age what logically result in acute recruitment needs for economy. Taking into consideration both innovative economy implementation and globalization processes it is highly necessary to supply labour force.

Foreign labour migration is a controversial phenomenon; much depends upon institutional differences and gaps, migration policies' history, cultural links, economy structure. Nowadays foreign labour migration demand both in the EU as well as in Russia is high. The census held in 2010 in Russia revealed that migration surplus in 1992-2010 amounted to 7 million people only and thus compensated 60 per cent or 13,1 million of natives' natural loss. Without this large-scale nomadism from the ex-USSR, Russian population would amount to 135,4 million instead of 142,9 million nowadays (Strategy 2020 2011). The challenge of the population ageing is widely perceived in Europe. Italy highlights that if Italians want to pursue the same life standards by the year 2050 , they will have to create 2,400 job places for migrants annually [18]. German chamber of trade claims that Germany lacks 400000 highly-qualified workers - this shortage costs 25 billion euro annually, what is equivalent to $1 \%$ of country's economic growth [1, c.151.].

Another important issue dealing with foreign labour migration is migrants' unwillingness to be integrated into society. Some scholars claim that "recipient society's values are not taken over" [1, c.152] and quite often migrants' costs exceed migrants' contribution to the recipient economies. This problem is also reflected in the

Corresponding Author: Maria Pitukhina/maria.pitukhina@gmail.com

$3^{\text {rd }}$ International Conference on Education, 20-22 April 2017, Kuala Lumpur, Malaysia 
EU literature. Most of the studies on foreign labour migration in Finland are handled by the Institute of Migration in Turku (E.Heikkilä, M.Pikkarainen, O.Koivukangas, A.-L.Toivanen, P.Kero, M.Niemi, I.Soderling, O.-K.Kaskinen). Few studies on foreign labourt migration inclusion into Russian labour market are mostly pursued by individual researchers (S.Shabayeva N.Parikova, M.Pitukhina, V.Mukomel, V.Iontsev, T.Zhigalina).

For the last years migration attractiveness has dropped in Russia. Society is constantly challenged with antimigration moods, while migrants themselves lack serious motivation to changes. Currently Russian migration policy is aimed at temporary labour migration and doesn't contribute to migrants' integration in the society [2].

Finland, Germany, and Australia pay much attention to this issue on a state level. This result in a migration policy, well-balanced and rationalized, aimed at both risks mitigation and recipients' economies benefitting. Obviously, foreign labour migration is a complex socio-political phenomenon playing the key role in economy. To a greater extent it conditions on country's socio-economic development.

Current article is dealing with neighboring migration policies analysis of Finland and Russia. Russia and Finland have a common geopolitical and historical context. Their border amounting to 1325,8 kilometers is the longest between Russia and the European Union.

The aim of the paper is to perform analysis of foreign labour migration influence on human capital development; to pursue a cross-country analysis; to outline the main challenges for the human capital development in Russia; to suggest measures aimed at overcoming challenges for the human capital development in Russia taking into account the best foreign practice (case of Finland).

Basic elements of Finnish migration policy were defined almost 20 years ago. Nowadays they are still topical: Act on the Integration of Immigrants and Asylum Seekers 493/1999 [10], Nationality Act 359/2003 [13], Aliens Act 301/2004 [12], Act on the Municipality of Domicile 201/1994 [11]. Fundamental principles of Russian migration policy are represented in the Constitution 12.12.1993. However, current economic situation demanded new legislation and thus a number of new conceptual documents have recently appeared: the President's "Decree on international consensus achievement" 7.05.2012 [8]; "Concept on state migration policy till 2025" 13.06.2012 [3]; "Strategy-2020: new growth model - new social policy" 14.03. 2012 [6].

Nowadays Finland is pursuing active migration policy aimed at migrants' integration on labour market by means of upgrading their language skills and qualification. Migrants' kids have an overall access to education, they also enjoy the right to study their mother-tongue. Finland is paying much attention towards multicultural education. Migrants' access to political participation is especially welcomed on regional and municipal levels they are entitled to vote and to be elected. Finland is taking the second place after Norway in terms of migrants' political participation flexibility. A wide spectrum of different laws prohibiting any kind of racial, religious, national discrimination is widely implemented in Finland. Migrants in Finland have a free access to legal assistance through a recently created office of Ombudsman for minorities.

All these principles were actually declared in Russia years ago, however, all the necessary documents were adopted in 2012.

Migration policy in Finland is considered to be highly adaptive, balanced, first of all preserving national interests. Success of such migration policy is conditioned on by implementing the best system of labour market parameters projection in Europe. The projection results are widely implemented by policymakers and citizens. Complementary and highly detailed statistic data is also a crucial issue.

While analyzing reasons for Finland's success we are highlighting the main aspects - quality and quantity of systemic approach on foreign labour migration in its diverse aspects - the best projection system of labour 
market parameters in Europe; foreign labour migration influence evaluation on human capital quality; VET development; skills anticipation; both information and research results dissemination in society; lifelong learning implementation.

\section{Defining human capital parameters}

Foreign labour migration influences both current and potential human capital development in a recipient country.

In one of the fundamental research on human capital dated 1982 "On the mechanics of economic development" [19] Lucas is giving the first definition to human capital - "the way it affects current production and the way the current time allocation affects the accumulation of it". Thus, Lucas believes that the principle feature of human capital is productivity in time. In Mankiw, Romer, and Weil paper dated 1992 and titled "A contribution to the empirics of economic growth" [20] authors perceive human capital through such parameters as: high income, technological changes, labour force growth. Gatman and Schonberg in their paper in 2008 on "How general is human capital? A task-based approach" claimed that the main human capital determinants are skills (Gatman and Schonberg 2008) [15].

Despite the fact that human capital is a complex phenomenon, it is possible to evaluate it by means of the Human Development Index. This is especially vital while performing cross-country analysis. The UN is calculating the Human Development Index for each country annually. The Human Development Index includes such parameters as lifetime, living standard, literacy, education. It would be pretty interesting to compare the countries parameters and observe how these criteria are implemented both in Russia and Finland:

- foreign labour migrants' vocational education;

- foreign labour migrants' Human Development Index.

\section{Foreign labour migrants' vocational education.}

Both in Russia and Finland it is widely perceived that low-qualified migrants will experience the layoff in the nearest future. In this terms human capital development is becoming crucial. As it is visible from the Table 1 foreign labour migration in Russia is characterized with a low-qualified workforce: migrants speak poor Russian, and main migration flows to Russia are mostly those with elementary vocational education. Huge numbers of labour migrants come from the Commonwealth of Independent States - Uzbekistan (41\%), Tajikistan (21.5\%), Ukraine (13.4\%), and Kirgizstan (9.4\%) [7, cc. 233-234]. The majority (86\%) of these foreign immigrants to Russia are male. Thus, the majority of foreign labour migrants in Russia are low-skilled [7]. Such a situation seriously contradicts many global trends mentioned in the WDR "skilled workers represent a growing share of international migration" [25, c.234]. However, there is explanation. For the last two decades Russia has been involved in an "overall" tertiary vocational education. In Russia in 1980ies there used to be only $40 \%$ of graduates from tertiary vocational education institutions, at the end of 1990ies this number rocketed and accounted for $75 \%$ [7]. This seriously challenged the occupational-qualification structure of the Russian labour market. In 1980s USSR, there used to be one manager for every three workers; nowadays there is one worker for every three managers [5]. Thus, our country has done a lot to contribute to the labour force shortage which is trying to be resolved via foreign labour migration nowadays. Such situation might cause serious negative outcomes, such as social tensions increasing and human capital degradation. Thus, quality of foreign labour migration tends to be a very acute problem in Russia especially in terms of labour force shortage and population ageing. 
Maria Pitukhina, Svetlana Shabayeva and Andrej Privara/ Cross-country analysis on neighboring migration policy by the example of Finland and Russia

Table 1 Redistribution of native workers and labour migrants in Russia in vocational education (per cent), 2011

\begin{tabular}{lcc}
\hline Level of vocational education & $\begin{array}{c}\text { Native workers in } \\
\text { Russia }\end{array}$ & Labour migrants in Russia \\
\hline Tertiary & $55 \%$ & $16 \%$ \\
\hline Secondary & $24 \%$ & $27 \%$ \\
\hline Elementary & $21 \%$ & $57 \%$ \\
\hline Total & $100 \%$ & $100 \%$ \\
\hline
\end{tabular}

However, in terms of innovative economy implementation it is highly important to reflect not only on qualitative aspect of foreign labour migrants. It is mentioned in the Concept on state migration policy till 2025 : "For the recent 2 decades migration surplus has increasingly substituted more than half of natural loss" [3], what is no doubt highly important. $\quad$ Nowadays human capital upgrading becomes highly crucial. In 2012 the President's "Decree on international consensus achievement" introduced "mandatory exams for foreign labour migrants in Russian language, Russian history, Russian legislation excluding those who are highly-qualified" [8]. Right after the Decree publication in May 250 assessment centers were open in Russian regions. Starting with the 1 January 2013 all migrants shall take exam in Russian language. Language tests were elaborated by 3 leading Russian Universities: Moscow State University, St.Petersburg State University and Russian University of People's Friendship. These tests include exercises in listening comprehension, grammar, and communication. 850 Russian words are set to be migrants' mandatory minimum. Starting with 2015 migrants shall take exams in Russian history and Russian legislation.

Table 2 below demonstrates native workers and foreign labour migrants redistribution in Finland by the vocational education level. It is visible that situation in Finland is very much different from Russian. Balance, the main feature of Finnish vocational system, is proved vividly with equal level of education both for migrants and native workers. Such situation is conditioned on by present-day realia, particularly, innovative economy implementation. Its successful implementation is possible due to its constant labour force development and of course shall be supported by political measures. In particular, the Finnish National Board of Education has developed a strategy titled "Learning and competence 2020" that stresses the development of civil skills such as creativity, interaction, active participation, self-expression, influence, self-education, responsibility what are resulting in "national intellectual capital" [23].

Table 2. Redistribution of native workers and labour migrants in Finland in vocational education (per cent), 2011

\begin{tabular}{lcc}
\hline Level of vocational education & $\begin{array}{c}\text { Native workers in } \\
\text { Finland }\end{array}$ & Labour migrants in Finland \\
\hline Tertiary & $37 \%$ & $33 \%$ \\
\hline Secondary & $45 \%$ & $42 \%$ \\
\hline Elementary & $18 \%$ & $25 \%$ \\
\hline Total & $100 \%$ & $100 \%$ \\
\hline
\end{tabular}

A broad picture on qualitative aspects of migration policy is represented with such index as Human development index (HDI) [24]. 
Foreign labour migrants’ Human Development Index

The major countries of origin for migrants in Finland are mainly the former Soviet Union (20 per cent), Sweden (12.8 per cent), Finland (10.3 per cent). (Fig.1).

\begin{tabular}{|c|c|c|c|}
\hline & \multirow[b]{2}{*}{ Country of birth } & \multicolumn{2}{|c|}{ Foreign-born } \\
\hline & & $(1000)$ & $(\%)$ \\
\hline \multirow{3}{*}{ IT } & Romania & 904.0 & 16.9 \\
\hline & Albania & 421.4 & 7.9 \\
\hline & Morocco & 392.1 & 7.3 \\
\hline \multirow{3}{*}{$\mathrm{LV}_{\mathrm{p}}$} & Russia & 1723 & 51.5 \\
\hline & Belarus & 57.9 & 17,3 \\
\hline & Ukraine & 424 & 127 \\
\hline \multirow{3}{*}{ NL } & Turkey & 197.4 & 10.6 \\
\hline & Suriname & 186.2 & 10.0 \\
\hline & Morocco & 167.7 & 9.0 \\
\hline \multirow{3}{*}{ PLp } & Ukraine & 155.5 & 28.6 \\
\hline & Germany & 71.5 & 13.1 \\
\hline & Former Soviet Union & 59.2 & 10.9 \\
\hline \multirow{3}{*}{ SI } & Bosnia and Herzegovina & 96.9 & 424 \\
\hline & Croatia & 49.2 & 21.5 \\
\hline & Serbia & 26.4 & 11.5 \\
\hline \multirow{3}{*}{ FI } & Former Soviet Union & 48.7 & 20.0 \\
\hline & Sweden & 31.2 & 128 \\
\hline & Estonia & 25.0 & 10.3 \\
\hline
\end{tabular}

Figure 1. Foreign labour migrants in Finland, 2011

The major countries of migrants origin in Russia are Uzbekistan (511,500), Tajikistan $(268,600)$, Ukraine $(167,300)$, and Kirgizia $(117,700)$ [9].

It is obvious that countries of origin for foreign labour migrants are different in cases of Russia and Finland. This is increasingly influencing human capital quality. It is obvious from the Table 3 that the Finnish Human Development Index is amounting to 0,882 and foreign labour migrants mostly possess very high, high or middle indexes. Russian human development index is amounting to 0,755 and foreign labour migrants mostly acquire middle and low indexes.

Table 3. HDI qualitative evaluation for foreign labour migrants in Russia and Finland

\begin{tabular}{lcc}
\hline $\begin{array}{l}\text { Country of origin of foreign } \\
\text { labour migration }\end{array}$ & $\begin{array}{c}\text { HDI of foreign labour } \\
\text { migrants in Finland }\end{array}$ & $\begin{array}{c}\text { HDI of foreign labour } \\
\text { migrants in Russia }\end{array}$ \\
\hline Germany & 0,905 & \\
\hline Sweden & 0,904 \\
\hline UK & 0,863 \\
\hline Estonia & 0,835 \\
\hline Serbia & 0,766 \\
\hline Russia & 0,755 \\
\hline China & 0,687 \\
\hline
\end{tabular}


Pitukhina, Shabayeva, Privara / Cross-country analysis on neighboring migration policy by the example of Finland and Russia

\begin{tabular}{lcl}
\hline Thailand & 0,682 & \\
\hline Iraq & 0,573 & \\
\hline Somalia & -- & \\
\hline Belorussia & 0,756 \\
\hline Kazakhstan & 0,745 \\
\hline Georgia & 0,733 \\
\hline Ukraine & 0,729 \\
\hline Armenia & 0,716 \\
\hline Azerbaijan & 0,700 \\
\hline Moldova & 0,649 \\
\hline Uzbekistan & 0,641 \\
\hline Kirgizia & 0,615 \\
\hline Tajikistan & 0,607 \\
\hline
\end{tabular}

Table 3 demonstrates that there is no equal substitution of natural loss with migration. To pursue current migration policy in Russia will result in human capital degradation while nowadays it is highly necessary to provide its development. As a result, we performed analysis of foreign labour migration influence on human capital development; pursued a cross-country analysis; outlined the main challenges for the human capital development in Russia; suggested measures aimed at overcoming challenges for the human capital development in Russia taking into account the best foreign practice (case of Finland).

\section{Outlining Finnish practice}

Migration policy in Finland is considered to be one of the most effective in the world. It is highly adaptive and balanced thoroughly preserving its national interests. Its success is conditioned on by:

1. The best system of labour market projection parameters in Europe.

2.Well-organized system of statistics representing unique data on foreign labour migrants in Finland.

1. The best system of labour market projection parameters in Europe. Finland is an example of a country which has designed a perfect system both for perspective skills monitoring and anticipation. Basic questions that are solved thanks to labour market parameters projection are: technological development future goals, education and innovations; pros and cons factors that influence the development.

Projection system in Finland is considered to be a complex and inter-related system. Its success is mainly conditioned on by a wide range of participants such as Finnish Parliament Committee, Ministry of education and culture, Finnish National Board on Education, Ministry of employment and the economy, Statistics of Finland, Regional councils, Centres for Economic Development, Transport and the Environment, association of municipal and regional authorities in Finland, universities, research institutes, other social partners.

One of the most useful instruments representing data for the interested actors is Occupational Barometer (OB) [21]. Description of both shortage and surplus occupations is performed for each administrative region of Finland.

Let's consider an example of such barometer for one of the Finnish regions (Fig.2). 


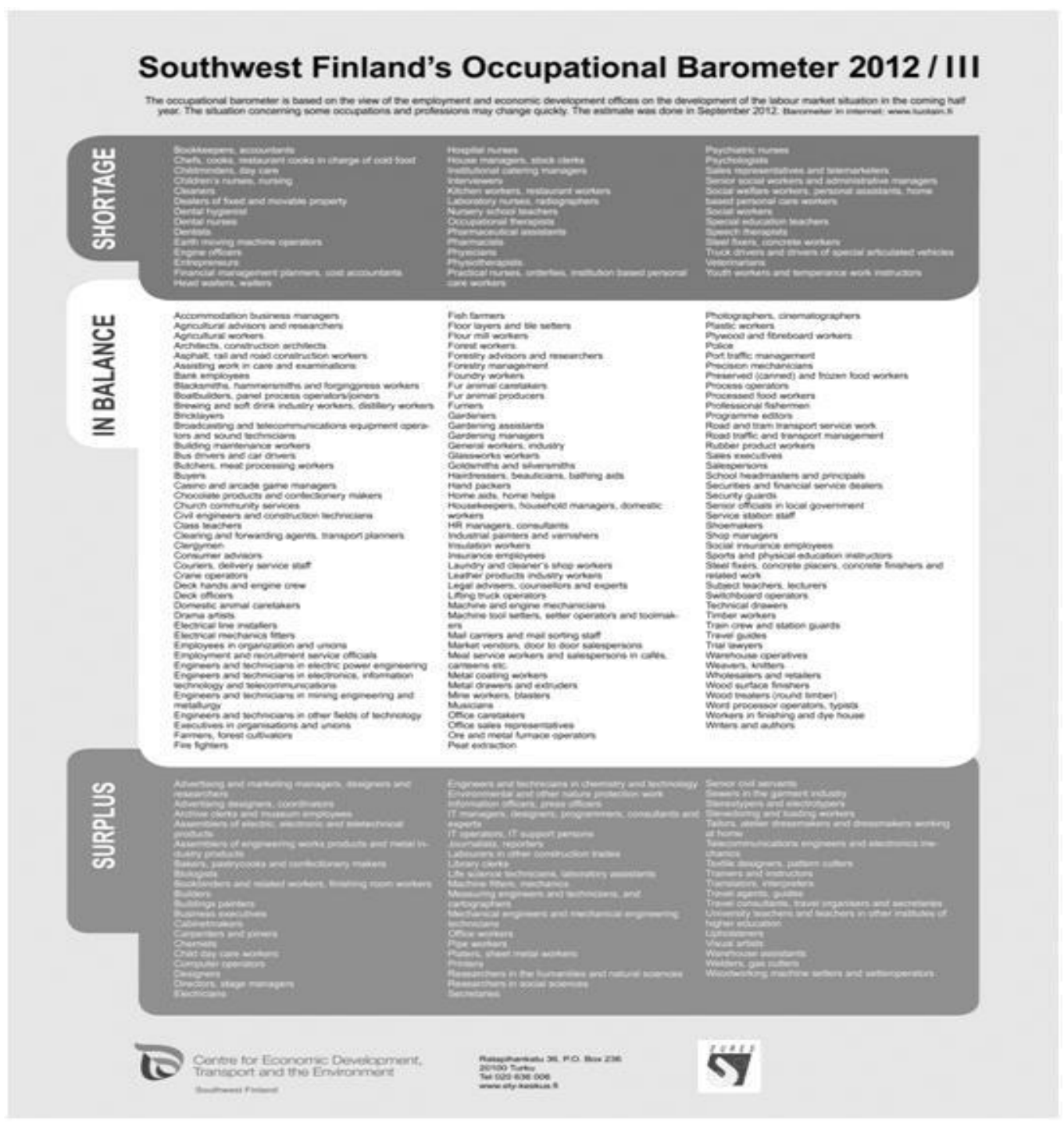

Figure 2. Southwest Finland's occupational barometer 2012/III

The above-mentioned OB represents data on 256 occupations for south-western labour market in Finland. It is obvious that nowadays Finland lacks social workers, therapists, and nurses. First of all, this is conditioned on by population ageing. OBs in Finland are developed for 11 administrative regions and might be accessed through the web-sites of the Centre for Economic Development, Transport and the Environment and TY-offices as well as in posters. Thus, Finnish population is constantly informed on labour market situation. This helps a lot in decision-making in choosing further educational or employment trajectories.

2. Well-organized system of statistics representing unique data on foreign labour migrants in Finland in terms of:

- migrants' employment by the country of origin,

- Finnish regions' attractiveness for migrants,

- gender balance in migrants' employment,

- migrants' employability in economic sectors, 
- migration unemployment rate,

-share of highly-skilled and low-skilled migrants.

Thus, statistics on «migrants' employment by the country of origin» reveals the highest level of employment for migrants from Estonia, the UK, Sweden, China, Turkey, the USA. Migrants from Iran, Somalia, Iraq, the former Yugoslavia Republic possess the lowest employment rates [16].

Gender balance in foreign labour migration is also picturesque. Females reveal the same employment results as males do - in trade (16\%), education and research (13\%), healthcare $(12 \%)$. These numbers don't seriously differentiate from those for males in trade (17\%), finances, insurance, business $(15 \%)$.

In Finland regions' attractiveness in the framework of foreign labour migration is studied thoroughly. Thus, Finnish Ahvenmaa possesses the most favorable conditions for migrants' employment. Second place goes to Uusimaa. It is obvious that southern Finland turns out to be the most attractive for migrants comparing to its northern part. Thus, in Lapland, Kainuu only $15 \%$ of migrants are able to find job [16].

Nowadays a well-organized system of statistics is absent in Russia. There is no detailed research on Russian regions' attractiveness for migrants, poor knowledge on feminization of migration on the labour market. It is highly necessary both to study and implement the Finnish model of foreign labour migrants in Russia.

\section{Conclusion}

Current situation in Russia and Finland is a result of measures taken by each country. Migration policy in Finland is first of all aimed at the Finnish society needs and results in negative factors annihilation. A complex system of preventive measures aimed at migrants' integration into Finnish society results in human capital development. A thoroughly planned system of different measures, consecutive implementation of these measures, migrants' adaptation in culture and language, results dissemination on labour market help Finland to overcome present-day challenges: population ageing, depopulation, productivity gap.

Russia is currently transforming its migration policy. High necessity of Russian transformations is highly obvious taking into consideration, in particular, Finnish experience. Russian migration policy should put the goals where the key-element will be Russian society's interests. It is obvious that full, valid, and up-to-date information will contribute to result-oriented decision-making. Information collecting on foreign labour migrants is far not enough, it is also important to apply it for further analysis of current situation on labour market and in decision-making. Data layout on foreign labour migrants by the Finnish example will contribute to further information dissemination on current and perceptive labour market situation. Finland's experience might become highly useful in finding solutions on foreign labour migration.

\section{Acknowledgements}

The article was prepared under the Strategic Development Program of Petrozavodsk State University.

\section{References}

Жигалина, М, 2011. Миграция как фактор развития человеческого потенциала мегаполиса, крупного города // Международная научно-практическая конференция "Германия и Россия: опыт и перспективы членства в ВТО" : материалы конференции/ ВШЭ СПб.- 16 апреля Санкт-Петербург. - 2011. - cc.151153. 
Итоговый доклад о результатах экспертной работы по актуальным проблемам социально-экономической стратегии России на период до 2020. Date of access: 01/05/2017 http://youngscience.ru/files/news-150312strateg2020.pdf .

Концепция государственной миграционной политики РФ на период до 2025 года. Date of access: 01/05/2017 http://www.kremlin.ru/acts/15635 .

Парикова, Н., Сигова, С., 2011. Влияние зарубежной трудовой миграци. Date of access: 01/05/2017 http://openbudgetrf.ru/doc/141/

Послание Президента ФС РФ 5/11/2008. Date of access: 01/05/2017 http://base.consultant.ru/cons/cgi/online.cgi?req=doc;base=LAW;n=81294.

Стратегия-2020: Новая модель роста - новая социальная политика. Date of access: 01/05/2017 http://www.intelros.ru/reports/13467-itogovyy-doklad-o-rezultatah-ekspertnoy-raboty-po-aktualnymproblemam-socialno-ekonomicheskoy-strategii-rossii-na-period-do-2020-goda-strategiya-2020-novaya-modelrosta-novaya-socialnaya-politika.html

Труд и занятость в России. 2010. Статистика: 233-234.

Указ Президента РФ от 7 мая 2012 года “Об обеспечении межнационального согласия”: Date of access: 01/05/2017 www.kremlin.ru

Федеральная служба статистики. 2010. Социально-экономические индикаторы. Регионы РФ, Москва: 252-288.

Act 1999. On the Integration of Immigrants and Reception of Asylum Seekers 493. Date of access: 01/05/2017 http://www.finlex.fi/en/laki/kaannokset/1999/en19990493.pdf

Act 1994. On the Municipality of Domicile 201 Date of access: 01/05/2017 www.stat.fi

Act 2004. Aliens Act 301. Date of access: 01/05/2017 http://www.finlex.fi/en/laki/kaannokset/2004/en20040301.pdf

Act 2003. Nationality Act 359. Date of access: 01/05/2017 http://www.finlex.fi/en/laki/kaannokset/2003/en20030359.pdf

EUROSTAT. Migrants in Europe. A statistical portrait of the first and second generation. Date of access: 01/05/2017 http://epp.eurostat.ec.europa.eu/cache/ITY_OFFPUB/KS-31-10-539/EN/KS-31-10-539-EN.PDF

Gatman, Ch., Schonberg, U. How general is human capital? A task-based approach, 2007. Date of access: 01/05/2017 http://www.cepr.org/meets/wkcn/4/4560/papers/GathmannFinal.pdf

Heikkilä, E., Pikkarainen, M., 2011. Internationalization of Population and Labour Forcefrom the Present to the Future in Finland. Date of access: 01/05/2017 http://www.aemi.dk/publications/AEMI\%20Journal\%200809.pdf?page $=169$

Inkeri repatriation has stopped. Finnish immigration service. Date of access: 01/05/2017 http://www.migri.fi/download/16763_paluumuuttojono_ru.pdf

Interview of professor Stefano Bianchini. Date of access: 01/05/2017 http://capriciosa.ru/ru/beseda-sprofessorom-universiteta-boloni-stefano-byankini.html

Lucas, R. On the mechanics of economic development, 1987. Date of access: 01/05/2017 http://www.parisschoolofeconomics.eu/docs/darcillon-thibault/lucasmechanicseconomicgrowth.pdf

Mankiw, N., Romer, D., Weil, D. A contribution to the empirics of economic growth, 1992. Date of access: 01/05/2017 http://www.amenezes.uac.pt/macroeconomiaII/macroeconomiaII_20062007/papers/mrw1992.pdf

Occupational barometer. Date of access: 01/05/2017 www.turku.fi/download.aspx?ID=91536\&GUID...D080$4 \mathrm{~A} 13$

OECD indicators. Education at glance. Date of access: 01/05/2017 http://www.oecd.org/education/highereducationandadultlearning/48631582.pdf

Strategy. Learning and competence 2020. Finnish National Board of Education. Date of access: 01/05/2017 http://www.oph.fi/download/135542_learning_and_competence_2020.pdf

UN report. Human Development Index Report. Date of access: 01/05/2017 http://hdr.undp.org/en/reports/global/hdr2011/download/ 
Pitukhina, Shabayeva, Privara / Cross-country analysis on neighboring migration policy by the example of Finland and Russia

World Development Report. Date of access: 01/05/2017

http://wdronline.worldbank.org/worldbank/a/c.html/world_development_report_2013/abstract/WB.978-0-82139575-2.abstract.

\section{Appendix}

\begin{tabular}{|c|c|c|c|}
\hline & & \multicolumn{2}{|c|}{ Foreign-born } \\
\hline & Country of birth & $(1000)$ & $(\%)$ \\
\hline \multirow{3}{*}{ IT } & Romania & 904.0 & 16.9 \\
\hline & Albania & 421.4 & 7.9 \\
\hline & Morocco & 392.1 & 7.3 \\
\hline \multirow{3}{*}{$\mathrm{LV}_{\mathrm{p}}$} & Russia & 1723 & 51.5 \\
\hline & Belarus & 57.9 & 17.3 \\
\hline & Ulkraine & 424 & 127 \\
\hline \multirow{3}{*}{ NL } & Turkey & 197.4 & 10.6 \\
\hline & Suriname & 186.2 & 10.0 \\
\hline & Morocco & 167.7 & 9.0 \\
\hline \multirow{3}{*}{ PLp } & Ukraine & 155.5 & 28.6 \\
\hline & Germany & 71.5 & 13.1 \\
\hline & Former Soviet Union & 59.2 & 10.9 \\
\hline \multirow{3}{*}{ SI } & Bosnia and Herzegovina & 96.9 & 424 \\
\hline & Croatia & 49.2 & 21.5 \\
\hline & Serbia & 26.4 & 11.5 \\
\hline \multirow{3}{*}{ FI } & Former Soviet Union & 48.7 & 20.0 \\
\hline & Sweden & 31.2 & 128 \\
\hline & Estonia & 25.0 & 10.3 \\
\hline
\end{tabular}

Figure 1. Foreign labour migrants in Finland, 2011 


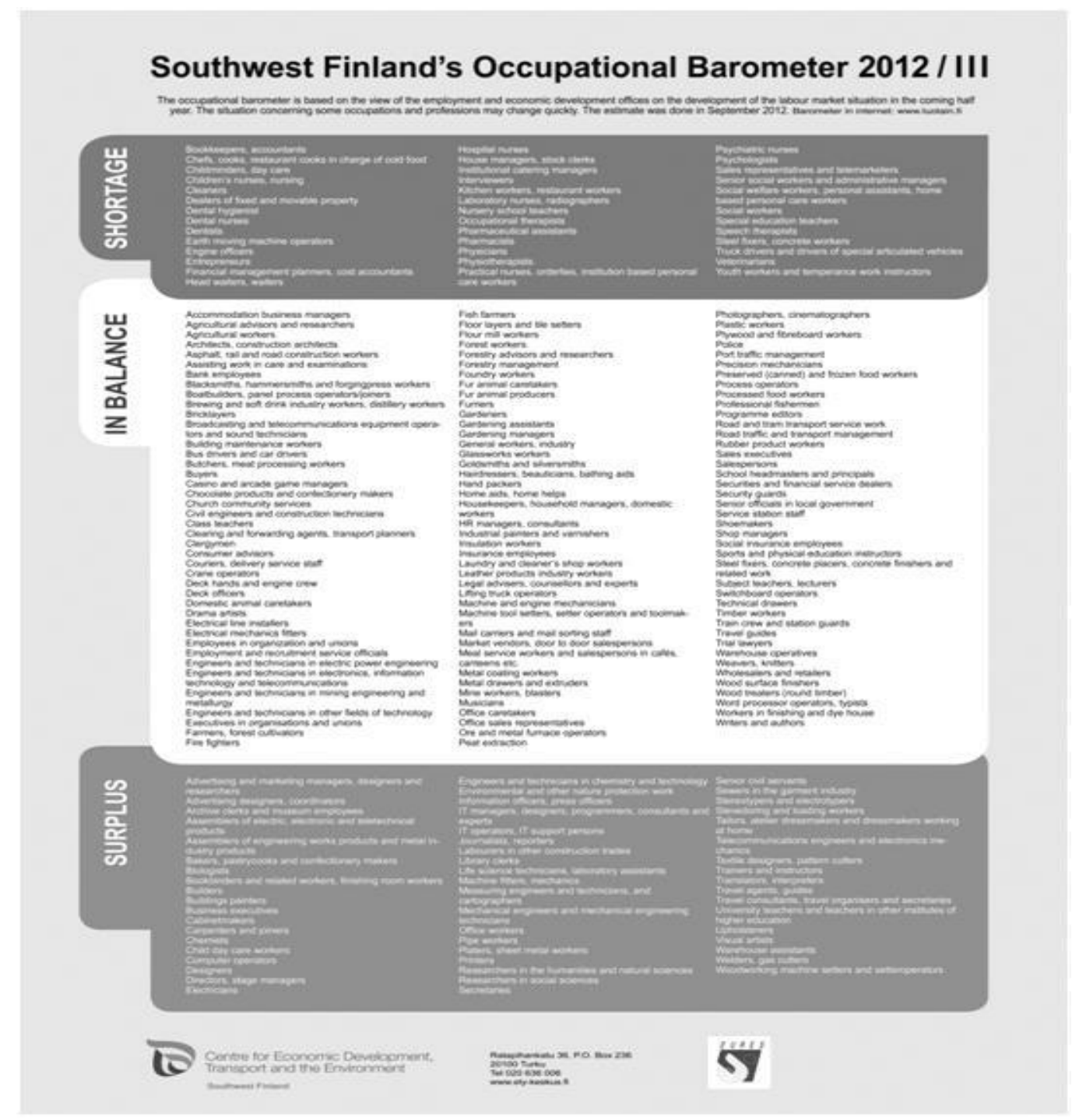

Figure 2. Southwest Finland's occupational barometer 2012/III

Table 1 Redistribution of native workers and labour migrants in Russia in vocational education (per cent), 2011

\begin{tabular}{lcc}
\hline Level of vocational education & $\begin{array}{c}\text { Native workers in } \\
\text { Russia }\end{array}$ & Labour migrants in Russia \\
\hline Tertiary & $55 \%$ & $16 \%$ \\
\hline Secondary & $24 \%$ & $27 \%$ \\
\hline Elementary & $21 \%$ & $57 \%$ \\
\hline Total & $100 \%$ & $100 \%$ \\
\hline
\end{tabular}


Pitukhina, Shabayeva, Privara / Cross-country analysis on neighboring migration policy by the example of Finland and Russia

Table 2. Redistribution of native workers and labour migrants in Finland in vocational education (per cent), 2011

\begin{tabular}{lcc}
\hline Level of vocational education & $\begin{array}{c}\text { Native workers in } \\
\text { Finland }\end{array}$ & Labour migrants in Finland \\
\hline Tertiary & $37 \%$ & $33 \%$ \\
\hline Secondary & $45 \%$ & $42 \%$ \\
\hline Elementary & $18 \%$ & $25 \%$ \\
\hline Total & $100 \%$ & $100 \%$ \\
\hline
\end{tabular}

Table 3. HDI qualitative evaluation for foreign labour migrants in Russia and Finland

\begin{tabular}{lcc}
\hline $\begin{array}{l}\text { Country of origin of foreign } \\
\text { labour migration }\end{array}$ & $\begin{array}{c}\text { HDI of foreign labour } \\
\text { migrants in Finland }\end{array}$ & $\begin{array}{c}\text { HDI of foreign labour } \\
\text { migrants in Russia }\end{array}$ \\
\hline Germany & 0,905 & \\
\hline Sweden & 0,904 \\
\hline UK & 0,863 & \\
\hline Estonia & 0,835 \\
\hline Serbia & 0,766 & \\
\hline Russia & 0,755 & \\
\hline China & 0,687 & 0,756 \\
\hline Thailand & 0,682 & 0,745 \\
\hline Iraq & 0,573 & 0,733 \\
\hline Somalia & -- & 0,729 \\
\hline Belorussia & & 0,716 \\
\hline Kazakhstan & & 0,700 \\
\hline Georgia & & 0,649 \\
\hline Ukraine & & 0,641 \\
\hline Armenia & & 0,615 \\
\hline Azerbaijan & & \\
\hline Moldova & & \\
\hline Uzbekistan & & \\
\hline Kirgizia & & \\
\hline Tajikistan & & \\
\hline & & \\
\hline
\end{tabular}

